\title{
ENZYMATIC FORMATION OF GLIDOBACTAMINE: A PEPTIDE NUCLEUS OF GLIDOBACTINS A, B AND C, NEW LIPOPEPTIDE ANTITUMOR ANTIBIOTICS
}

\author{
Kei-ichi Numata, Masahisa Oka, Yasukazu Nakakrta, \\ Tsutomu Murakami, Takeo Miyaki, Masataka Konishi, \\ ToshikazU OKI and Hiroshi KaWaguchi
}

Bristol-Myers Research Institute, Ltd., Tokyo Research Center, 2-9-3 Shimo-meguro, Meguro-ku, Tokyo 153, Japan

(Received for publication March 25, 1988)

\begin{abstract}
Glidobactin deacylating activity was found in a bacterial strain of Pseudomonas sp. Glidobactamine, a key intermediate for acyl analogues of glidobactin, was isolated from the enzymatic degradation products of glidobactins after treatment using a column of fibrous active gel on which the cells of the Pseudomonas strain were immobilized. The chemical structure of glidobactamine was confirmed as the intact peptide moiety of glidobactins by chemical reformation of glidobactin A from glidobactamine and 2,4-dodecadienoic acid which is the constitutive fatty acid of glidobactin A.
\end{abstract}

Glidobactins A, B and C, new lipopeptide antitumor antibiotics were isolated from the fermentation broth of Polyangium brachysporum sp. nov. strain ATCC 53080.12 Their chemical structures were determined as shown in Fig. 1, through the chemical and enzymatic degradation and the subsequent spectral analyses. Papain cleavage of glidobactin A at site B, as shown in Fig. 1, afforded a cyclic amine designated as glidobamine $(\mathrm{V})$ and $2(E), 4(E)$-dodecadienoyl-L-threonine, giving important information for the structure elucidation of glidobactins. ${ }^{2)}$ On the other hand, another enzymatic cleavage at site A should give a useful intermediate for preparing diverse semisynthetic analogues of the antibiotic. This type of approach has been successfully applied in an industrial scale for enzymatic

Fig. 1. Chemical structure and the possible enzymatic cleavage sites of glidobactins.

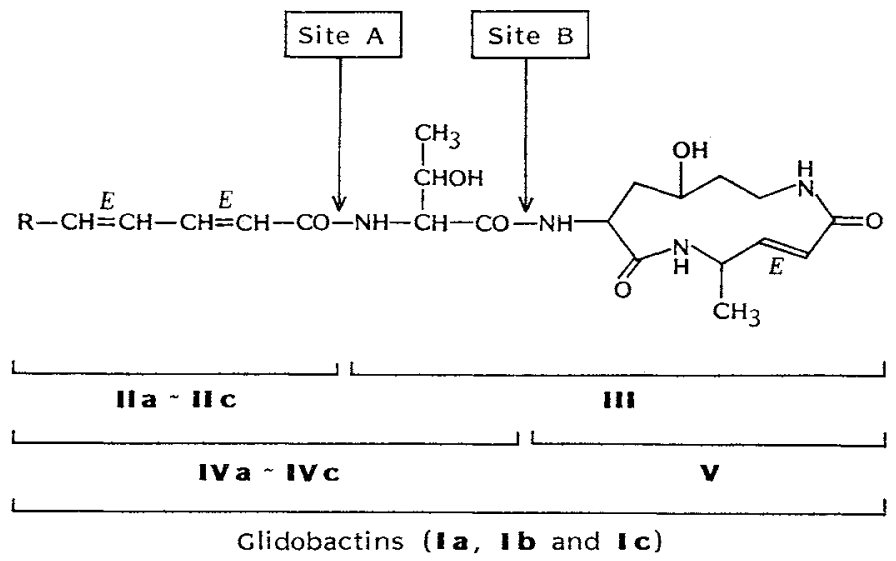

Glidobactin A (Ia), IIa and IVa R $=\mathrm{CH}_{3}\left(\mathrm{CH}_{2}\right)_{6^{-}}$

Glidobactin B (Ib), $\mathrm{Ib}$ and IVb $\mathrm{R}=\mathrm{CH}_{3}\left(\mathrm{CH}_{2}\right)_{4} \mathrm{CH}=\mathrm{CH}\left(\mathrm{CH}_{2}\right)_{2}-$

Glidobactin C (Ic), Ile and IVe $\mathrm{R}=\mathrm{CH}_{3}\left(\mathrm{CH}_{2}\right)_{5}-$ 
removal of the side chain and subsequent modification of penicillins and cephalosporins..$^{3 \sim 5)}$ Our attempts to cleave at site $\mathrm{A}$ by means of chemical methods or by the enzymatic hydrolysis using available acylases and peptidases were unsuccessful. However, some acylases have been reported to cleave acyl side chains of lipopeptide antibiotics. ${ }^{8 \sim 8\rangle}$ Therefore, we initiated studies to isolate microorganisms producing glidobactin acylases, and found such activity in a bacterial strain UCD-258.

The present paper describes the isolation, characterization and identification of the acylaseproducing microorganism, the enzymatic preparation and the properties of deacylated peptide nucleus designated as glidobactamine.

\section{Materials and Methods}

\section{Chemicals}

Glidobactins A, B and C (Ia, Ib and Ic) and authentic samples of their degradation products (IIa, IIb, IIc, IVa and V) were prepared by the methods described in the previous paper. ${ }^{1,2}$ Sodium alginate (Wako), CM-cellulose (Serva), $p$-nitroaniline (Sigma) and lauroyl chloride (Wako) and others were purchased from the respective commercial sources.

\section{Preparation of Lauroyl $p$-Nitroanilide}

$p$-Nitroaniline $(500 \mathrm{mg}$ ) was acylated with $4 \mathrm{~g}$ of lauroyl chloride in aqueous alkaline acetone solution. The reaction product was isolated as oily residue by extraction with EtOAc at acidic $\mathrm{pH}$ after 2-hour reaction at room temp and then applied onto silica gel column $(2 \times 16 \mathrm{~cm})$. After washing the column with $n$-hexane, the desired product was eluted with $n$-hexane - EtOAc $(5: 1)$ by monitoring UV absorption and TLC. The colorless fractions containing the compound were collected and dried in vacuo. The oily residue was crystallized in aqueous $\mathrm{MeOH}$ to afford $728 \mathrm{mg}$ of colorless needle. The structure of this compound was confirmed by UV, IR and NMR spectra.

\section{Isolation and Cultivation of Microorganisms}

Soil samples were inoculated into tubes with $5 \mathrm{ml}$ of modified BENNETT's agar medium (rB) containing soluble starch $0.5 \%$, glucose $0.5 \%$, meat extract $0.1 \%$, yeast extract $0.1 \%$, NZ-case $0.2 \%$, $\mathrm{NaCl} 0.2 \%$ and $\mathrm{CaCO}_{3} 0.1 \%$. After incubation for 18 hours at $28^{\circ} \mathrm{C}$, the broth was appropriately diluted with saline and then spread on $\mathrm{rB}$ agar plates (containing the same ingredients described above with $1.4 \%$ agar) with different growth inhibitors. After 2 to 4 days of incubation at $28^{\circ} \mathrm{C}$, each colony formed on the plates was picked up and transferred to $\mathrm{rB}$ agar slant. One loopful of bacterial cells well-grown on the agar slant was inoculated into a liquid medium in an Erlenmeyer flask. The flask was incubated on a rotary shaker at $28^{\circ} \mathrm{C}$.

\section{Preparation of Immobilized Cells}

Bacterial cells harvested from $100 \mathrm{ml}$ of broth by centrifugation, washed with saline twice and resuspended in $5 \mathrm{ml}$ of saline. The cell suspension was mixed with pre-autoclaved suspension $(10 \mathrm{ml})$ of sodium alginate $(0.5 \mathrm{~g})$ and $\mathrm{CM}$-cellulose $(0.5 \mathrm{~g})$, and the mixture was poured into $200 \mathrm{ml}$ of $0.1 \mathrm{M}$ $\mathrm{CaCl}_{2}$ solution under stirring to afford fibrous gel entrapped the cells. The gel was further treated with addition of $0.5 \mathrm{ml}$ of $25 \%$ glutaraldehyde solution for 1 hour at room temp.

\section{Characterization and Identification of the Bacterial Strain}

The taxonomic characteristics of bacterial strains which showed the acylase activity were examined according to the descriptions in BERGEY's Manual of Systematic Bacteriology ${ }^{\theta)}$ and the handbook edited by STOLP and GADKARI. ${ }^{10)}$

\section{Assay of Glidobactin Degrading Activity}

DMSO solution of glidobactin A $(2.0 \mathrm{mg} / \mathrm{ml}, 0.05 \mathrm{ml})$ was added to $0.5 \mathrm{ml}$ of the cell suspension in $0.1 \mathrm{M}$ phosphate buffer ( $\mathrm{pH} \mathrm{7.0)}$. The mixture was vortexed and incubated for 18 hours at $37^{\circ} \mathrm{C}$. The reaction was stopped by addition of $0.5 \mathrm{ml}$ of $\mathrm{MeOH}$ and the mixture was shaken vigorously for 15 minutes at room temp and then centrifuged at $5^{\circ} \mathrm{C}$. Glidobactin $\mathrm{A}$ in the supernatant was de- 
termined by the paper-disc agar diffusion method against Candida albicans A9540 or by HPLC (Waters QA-1 analyzer with Radial Pak $\mathrm{C}_{18}$ ). Degrading activity was estimated by a residual amount of glidobactin $A$.

Assay of Lauroyl $p$-Nitroanilide Hydrolyzing Activity

DMSO solution of lauroyl $p$-nitroanilide solution $(4 \mathrm{mg} / \mathrm{ml}, 0.05 \mathrm{ml})$ was added to $0.5 \mathrm{ml}$ of the cell suspension in $0.1 \mathrm{~m}$ phospate buffer $(\mathrm{pH} 7.0)$. The mixture was vortexed and incubated for 4 hours at $37^{\circ} \mathrm{C}$. The incubation was continued for 18 hours to screen the activity. The reaction was stopped by addition of $0.05 \mathrm{ml}$ of $\mathrm{AcOH}$ and the mixture was centrifuged at $5^{\circ} \mathrm{C}$. An aliquot of the supernatant was transferred to 96 -well microtiter plate. Absorbancy at $415 \mathrm{~nm}$ was determined by ELIZA analyzer ETY-96 (Toyo Sokki Ltd.).

\section{Coupling of Glidobactamine and 2(E),4(E)-Dodecadienoic Acid}

A dimethylformamide solution $(1 \mathrm{ml})$ of $\mathbf{\Pi a}(3.4 \mathrm{mg}), N, N^{\prime}$-dicyclohexylcarbodiimide $(3.7 \mathrm{mg})$ and 1-hydroxy-1,2,3-benzotriazole $(2.8 \mathrm{mg})$ was stirred for 2 hours at room temp. To the solution was added glidobactamine $(5 \mathrm{mg})$ and the mixture was kept stirring for additional 3 hours and concentrated in vacuo. The residue was dissolved in $\mathrm{MeOH}$ and purified by preparative HPLC (SSCODS-842 column; mobile phase: $90 \%$ aqueous $\mathrm{MeOH}$ ). Evaporation of the active fraction gave glidobactin A $(4.0 \mathrm{mg}$, yield $45 \%)$.

\section{Chemical Synthesis of Compound III}

To a stirred mixture of $N$-tert-butoxycarbonyl(BOC)-L-threonine (44 $\mathrm{mg}, N, N^{\prime}$-dicyclohexylcarbodiimide $(40 \mathrm{mg})$ and 1-hydroxy-1,2,3-benzotriazole $(30 \mathrm{mg})$ in DMF $(4 \mathrm{ml})$ was added glidobamine $(\mathbf{V}, 40 \mathrm{mg})$ at room temp. After concentrated the mixture, $51 \mathrm{mg}$ of $N$-BOC-L-threonyl-V (BOC-III, yield $69 \%$ ) was isolated by column chromatography of reversed phase silica $\left(\mathrm{C}_{18}, 40 \mathrm{ml}\right)$ with aqueous $\mathrm{MeOH}(10 \%$ to $40 \%$ of $\mathrm{MeOH})$. BOC-III showed IR-absorption maxima in $\mathrm{KBr}$ at 1690 and $1640 \mathrm{~cm}^{-1}$, and the following proton signals in its NMR spectrum $(80 \mathrm{MHz})$ in DMSO- $d_{6}$ : $\delta 1.00(3 \mathrm{H}, \mathrm{d}, J=7.5 \mathrm{~Hz}), 1.22(3 \mathrm{H}, \mathrm{d}, J=7.5 \mathrm{~Hz}), 1.35(9 \mathrm{H}, \mathrm{s}), 6.11(1 \mathrm{H}, \mathrm{d}, J=18 \mathrm{~Hz})$ and $6.33(1 \mathrm{H}$, dd, $J=5.0$ and $18 \mathrm{~Hz}$ ). BOC-III $(36 \mathrm{mg}$ ) was deblocked by 1-hour stirring in formic acid $(1 \mathrm{ml})$ at room temp and the subsequent reversed phase chromatographic purification afforded $25 \mathrm{mg}$ of pure compound III (yield $88 \%$ ).

\section{Results and Discussion}

\section{Screening of Glidobactin Acylase Producing Strains}

As deacylated products of glidobactin were thought to lose or decrease its intact antibiotic activity from the previous knowledge on acylases which could act upon acyl side chain of antibiotics, the glidobactin degrading activity was first searched among freshly isolated 150 cultures (135 bacterial and 15 fungal strains) and 50 cultures kept in our laboratory (40 bacterial and 10 fungal strains). The majority of fungal strains (17 cultures) and 8 bacterial cultures showed the activity. These cultures were selected by their ability to hydrolyze lauroyl $p$-nitroanilide as a mimic substrate of glidobactin acylase in order to eliminate site B cleavage and other modification to lose the antibiotic activity. As shown in Table 1, six bacterial and five fungal strains showed the acylase activity to the mimic substrate. In the HPLC of reaction products by strain UCD-258, identical peak of $2(E), 4(E)$-dodecadienoic acid (IIa) was clearly observed. However, the detection of residual peptide moiety on TLC was failed because of amine impurities originating from the enzymatic source. Immobilization of the cells permitted to avoid this problem and led to successful detection of glidobactamine on account of co-fixation of the impure amines. The recycling effluent of the solution of glidobactin A through the column packed with the entrapped UCD-258 cells showed a ninhydrin positive spot at Rf 0.20 and two UV spots at Rf 0.56 and 0.78 on silica gel TLC as shown in Fig. 2. The later two UV spots 
were identical with glidobactin A (Ia) and 2(E),4(E)-dodecadienoic acid (IIa), respectively. The Rf value of ninhydrin positive spot was identical with that of chemically synthesized compound III which was obtained from the coupling of glidobamine (V) and L-threonine.

\section{Characterization and Identification of Strain UCD-258}

The strain UCD-258 was aerobic, Gram-negative, non-sporulating rods $(0.7 \sim 1.1 \times 1.5 \sim 3.0 \mu \mathrm{m})$ with round ends. Motility was observed with multiple polar flagellation (Fig. 3). Colonies on a nutrient agar were circular, flat and smooth with colorless. Indole production and VP reaction were negative. Growth was observed at 20 and

Table 1. Glidobactin degrading and acylase activities of primary active strains.

\begin{tabular}{cccl}
\hline $\begin{array}{c}\text { Strain } \\
\text { No. }\end{array}$ & $\begin{array}{c}\text { Degradation } \\
\text { of } \\
\text { glidobactin } \\
(\%)\end{array}$ & $\begin{array}{c}\text { Formation } \\
\text { of } \\
\text { nitroaniline } \\
(\%)\end{array}$ & Remarks \\
\hline UCD-105 & 74 & 25 & Fungi \\
UCD-111 & 86 & 48 & Gn bacteria \\
UCD-226 & 68 & 87 & Fungi \\
UCD-227 & 99 & 27 & Fungi \\
UCD-231 & 83 & 100 & Fungi \\
UCD-232 & 89 & 99 & Fungi \\
UCD-254 & 91 & 19 & Gn bacteria \\
UCD-258 & 98 & 82 & Gn bacteria \\
D-386 & 98 & 98 & Gn bacteria \\
D-395 & 99 & 90 & Gn bacteria \\
E-003 & 99 & 30 & Gn bacteria \\
\hline
\end{tabular}

The activities were measured after 18 -hour incubation using the cells in $1.5 \mathrm{ml}$ of fermentation broth.

Gn: Gram-negative.

Fig. 2. Silica gel TLC of glidobactin acylase products.

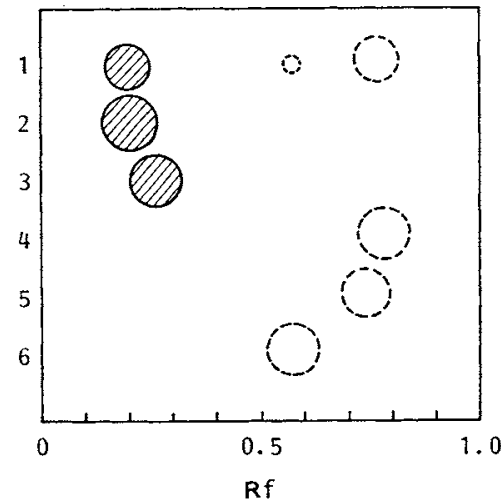

$$
\begin{aligned}
& \text { UV-lamp } \\
& \text { Ninhydrin reaction }
\end{aligned}
$$

TLC was developed with $\mathrm{BuOH}-\mathrm{AcOH}-\mathrm{H}_{2} \mathrm{O}$ $(3: 1: 1)$. Spots were detected under UV-lamp and then ninhydrin reaction. Lane 1 , the acylase products; lane 2 , chemically synthesized compound III; lane 3, compound V; lane 4, compound IIa; lane 5, compound IVa and lane 6, glidobactin A.

Fig. 3. Transmission electron micrographs of strain UCD-258 by the negative stain method. (a) $\times 7,500$, (b) $\times 15,000$. Bars represent $1 \mu \mathrm{m}$.

(a)

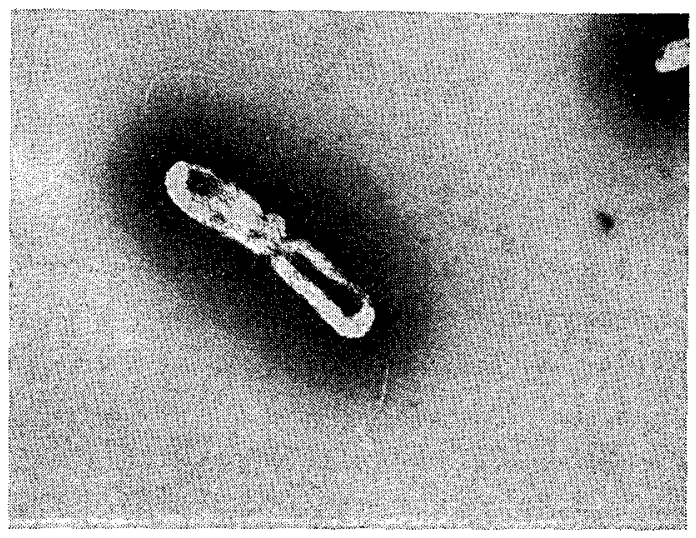

(b)

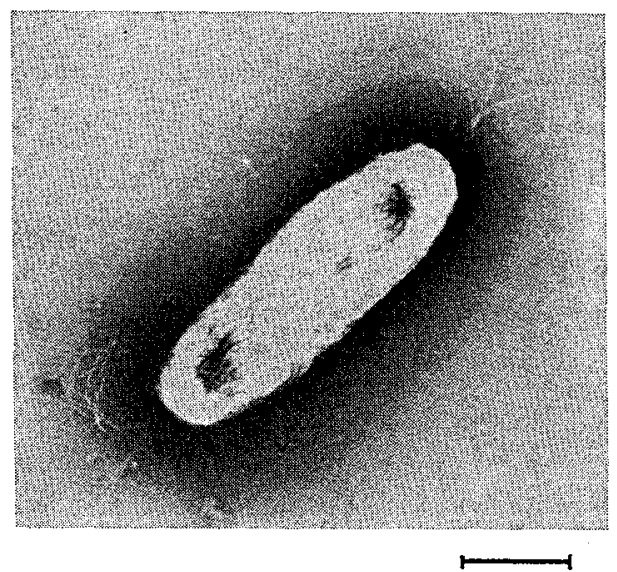


$37^{\circ} \mathrm{C}$, but not at 5 or $43^{\circ} \mathrm{C}$. The strain did not demand any growth factors. Physiological properties are summarized in Table 2.

These taxonomic features of strain UCD258 were thought to fall into those of the genus Pseudomonas. The strain UCD-258 seemed to be closely related to Pseudomonas acidovorans. Recently, a very similar strain, Pseudomonas M6-3 was independently reported as a polymyxin acylase producing strain. ${ }^{7)}$ The difference was observed only in gelatin liquefaction of UCD258 so far tested in comparison with the descriptions on the strain M-6-3. The substrate specificity of the acylase produced by strain UCD-258 to other lipopeptide antibiotics will be compared to that of polymyxin acylase from strain M-6-3.
Table 2. Physiological properties of strain UCD258.

\begin{tabular}{ll}
\hline Catalase & Positive \\
Oxidase & Positive \\
Indole production & Negative \\
OF test (glucose) & Negative (alkaline) \\
VP reaction & Negative \\
Starch hydrolysis & Negative \\
Gelatin liquefaction & Negative \\
Nitrate reduction & Positive \\
Growth temperature & $15 \sim 37^{\circ} \mathrm{C}$ \\
Growth pH & $5.0 \sim 11.3$ \\
Utilization of citrate & Positive \\
Formation of fluorescent & Negative \\
pigment & \\
Accumulation of PHB & Positive \\
Arginine dihydrolase & Negative \\
Denitrification & Negative \\
Growth factor & No requirement \\
Utilization of testosterone & Negative \\
Protocatechuate & meta-Cleavage \\
\hline
\end{tabular}

Enzymatic Formation and Isolation of Glidobactamine

Since the ninhydrin positive spot produced by the immobilized UCD-258 cells was thought to be the desired product, large scale preparation of glidobactamine was attempted. Overnight culture of strain UCD-258 in $\mathrm{rB}$ medium was used for inoculation. Each $1.5 \mathrm{ml}$ of the vegetative cells was transferred to $500-\mathrm{ml}$ Erlenmeyer flasks with $100 \mathrm{ml}$ of the medium containing soluble starch $2 \%$, glucose $0.2 \%$, soybean meal $3 \%, \mathrm{CaCO}_{3} 1 \%$ and $\mathrm{MgSO}_{4} \cdot 7 \mathrm{H}_{2} \mathrm{O} 0.3 \%$. Acylase activity reached a maximum after rotary-shaking for $2 \sim 3$ days at $28^{\circ} \mathrm{C}$.

The cells were harvested from 10 liters of the broth by filtration and centrifugation. After being washed with saline (1 liter) twice, the cells were resuspended in $750 \mathrm{ml}$ of saline, and immobilized with algin and CM-cellulose by the method described in Materials and Methods. A solution of glidobactin $\mathrm{A}(1.5 \mathrm{~g})$ in $20 \%$ aqueous methanol (30 liters) was passed through the column $(4 \times 175 \mathrm{~cm})$ at flow rate of $0.4 \sim 0.8$ liter/hour. The pooled effluent was then passed through an Amberlite IRC-50 $(70 \%$ ammonium form, $\mathrm{pH} 6.7,300 \mathrm{ml})$ and Diaion HP-20 column $(300 \mathrm{ml})$ successively. The IRC50 column was washed with water and then developed with $1.5 \mathrm{~N} \mathrm{NH}_{4} \mathrm{OH}$. The ninhydrin positive fractions were pooled, concentrated and lyophilized to give pale yellow solid $(800 \mathrm{mg})$. The reversed phase silica $\left(\mathrm{C}_{18}, 250 \mathrm{ml}\right)$ column was developed with water under medium-pressure and ninhydrinpositive eluates were pooled and concentrated to afford $612 \mathrm{mg}$ of glidobactamine as white amorphous solid (yield $62 \%$ ), but the compound $\mathrm{V}$, a product hydrolyzed at site $\mathrm{B}$, was not detected. These results indicate that the active gel would act specifically on the peptide bond at site A.

After five cycles of the reaction in the same scale during 15 days, the gel still retained more than $75 \%$ of hydrolytic activity. Furthermore, even after 6 -month preservation in deionized water at $5{ }^{\circ} \mathrm{C}$, the gel retained approximately $25 \%$ of the initial activity.

\section{Properties and Chemical Structure of Glidobactamine}

Glidobactamine did not exhibit any antifungal and antitumor activities. Amorphous solid of glidobactamine did not show clear mp below $170^{\circ} \mathrm{C}$, and it showed $[\alpha]_{\mathrm{D}}^{27}-157^{\circ}\left(c 0.5, \mathrm{H}_{2} \mathrm{O}\right)$, end ab- 
sorption in UV spectrum, and the following absorptions in IR spectrum $(\mathrm{KBr}) \mathrm{cm}^{-1} 3350,3280,1650$, 1620,1530 . Molecular weight of glidobactamine is deduced 342 by the electron impact (EI)-MS. A monohydrochloride sample was analyzed for $\mathrm{C}_{15} \mathrm{H}_{28} \mathrm{~N}_{4} \mathrm{O}_{5} \cdot \mathrm{HCl} \cdot 2 \mathrm{H}_{2} \mathrm{O}$.

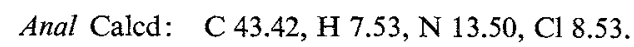

Found: C 43.94, H 7.34, N 13.42, Cl 7.99.

In the NMR spectrum of glidobactamine in DMSO- $d_{9}, 19$ protons assignable to those of the peptide nucleus of glidobactin were observed at $\delta 1.05(3 \mathrm{H}, \mathrm{d}, J=7.5 \mathrm{~Hz}), 1.21(3 \mathrm{H}, \mathrm{d}, J=7.5 \mathrm{~Hz}), 1.4 \sim 2.2$ $(4 \mathrm{H}, \mathrm{m}), 4.35(2 \mathrm{H}, \mathrm{m}), 4.47(1 \mathrm{H}, \mathrm{br} \mathrm{d}, \mathrm{OH}), 4.62(1 \mathrm{H}, \mathrm{d}, J=6.5 \mathrm{~Hz}, \mathrm{OH}), 6.16(1 \mathrm{H}, \mathrm{d}, J=15.5 \mathrm{~Hz})$, $6.42(1 \mathrm{H}, \mathrm{dd}, J=6.5$ and $15.5 \mathrm{~Hz}), 7.36(1 \mathrm{H}, \mathrm{t}, J=4.5 \mathrm{~Hz}, \mathrm{NH}), 7.97(1 \mathrm{H}, \mathrm{d}, J=8.5 \mathrm{~Hz}, \mathrm{NH})$ and $8.62(1 \mathrm{H}, \mathrm{d}, J=7.5 \mathrm{~Hz}, \mathrm{NH})$.

Terminal amine moiety of glidobactamine was determined as L-threonine by the DNP-method and further confirmed by the chemical synthesis of compound III. Coupling experiment with glidobactamine and 2,4-dodecadienoic acid (IIa) led the reformation of glidobactin A (Ia) which was identical to the natural antibiotic. From these results, chemical structure of glidobactamine was determined as the desired key intermediate (III), the peptide nucleus of glidobactins.

Isolation and Identification of Liberated Fatty Acids

The Diaion HP-20 (column obtained when prepared glidobactamine) was developed with water (1 liter) and then a mixture of $0.1 \mathrm{~N} \mathrm{NaOH}$ and $\mathrm{MeOH}(1: 2)$. Fractions containing the chromophore were pooled, concentrated to $300 \mathrm{ml}$ and acidified to $\mathrm{pH} 2.0$. This solution was extracted with EtOAc $(300 \mathrm{ml})$. Evaporation of the extract gave an oily residue which was chromatographed on a column of Sephadex LH-20 $(800 \mathrm{ml})$. Upon elution with $\mathrm{MeOH}$, the appropriate eluates containing the chromophore, which has UV-maximum around $260 \mathrm{~nm}$, were concentrated to afford $259 \mathrm{mg}$ of colorless plates (yield $53 \%$ ). This crystal of fatty acid showed the following physico-chemical properties. MP $48 \sim 49^{\circ} \mathrm{C}$; UV $\lambda_{\max }^{\mathrm{MeOH}} \mathrm{nm}(\varepsilon) 258(24,000)$; IR $\nu_{\max }^{\mathrm{KBr}} \mathrm{cm}^{-1} 1680,1630,1605,1410$, $1300 ;{ }^{1} \mathrm{H}$ NMR $\left(80 \mathrm{MHz}, \mathrm{CD}_{3} \mathrm{OD}\right) \delta 0.89(3 \mathrm{H}, \mathrm{t}, J=7.5 \mathrm{~Hz}), 2.0(10 \mathrm{H}, \mathrm{m}), 2.12(2 \mathrm{H}, \mathrm{m}), 5.75(1 \mathrm{H}$, $\mathrm{d}, J=16 \mathrm{~Hz}), 6.16(2 \mathrm{H}, \mathrm{m})$ and $7.21(1 \mathrm{H}, \mathrm{m})$. This compound was identical with the authentic sample of $2(E), 4(E)$-dodecadienoic acid (IIa).

When treated glidobactins B and C (20 mg each) by the same procedure, they afforded glidobactamine and different fatty acids. Methyl esters of the fatty acids, prepared by treatment with diazomethane in ethyl ether, gave protonated molecular ion peaks at $m / z 237$ and 239 in their chemical ionization (CI)-MS spectra, respectively. These compounds were identical with authentic samples of $2(E), 4(E), 8(Z)$-tetradecatrienoic acid (IIb) and $2(E), 4(E)$-tetradecadienoic acid (IIc), respectively.

No existence of compounds IVa, IVb or IVe in the eluates of Diaion HP-20 column also indicated that the immobilized acylase could hydrolyze glidobactin A, B or C only at site A. Further properties of this enzyme will be examined when the acylase is purified.

\section{Acknowledgments}

The authors express deep thanks to Prof. M. OHASHI, University of Electrocommunication, for the mass spectroscopic analysis and valuable suggestions. Thanks are also due to Dr. T. Tsuno and his co-workers for their spectral analyses and Messrs. T. KADOTA and H. CHIKASAWA for the electron micrographs.

\section{References}

1) OKa, M.; Y. Nishiyama, S. Ohta, H. Kamei, M. Konishi, T. Miyaki, T. OKi \& H. Kawaguchi: Glido- 
bactins A, B and C, new antitumor antibiotics. I. Production, isolation, chemical properties and biological activity. J. Antibiotics 41:1331 1337, 1988

2) OKa, M.; K. Yaginuma, K. Numata, M. Konishi, T. OKI \& H. KawaGuChi: Glidobactins A, B and C, new antitumor antibiotics. II. Structure elucidation. J. Antibiotics 41:1338 1350, 1988

3) Cole, M.; T. Savidge \& H. Vanderhaeghe: [54a] Penicillin acylase (assay). In Methods in Enzymology. Volume XLIII Antibiotics. Ed., J. H. HASH, pp. 698 728, Academic Press, New York, 1975

4) VANDAMme, E. J. \& J. P. Voets: Microbial penicillin acylase. Adv. Appl. Microbiol. 17: 311 367, 1974

5) Lowe, D. A.; G. Romancik \& R. P. Elander: Penicillin acylases: Review of existing enzymes and the isolation of a new bacterial penicillin acylase. Dev. Ind. Microbiol. 22: 163 180, 1981

6) Weber, J. M. \& D. Perlman: Amphomycin acylase. J. Antibiotics 31: 373 374, 1978

7) Kimura, Y.; H. Matsunaga, N. Yasuda, T. Tatsuki \& T. Suzuki: Polymyxin acylase: a new enzyme for preparing starting materials for semi-synthetic polymyxin antibiotics. Agric. Biol. Chem. 51: 1617 1623,1987

8) AввотT, B. J.; M. Debono \& D. S. Fukuda (Eli Lilly): A-21978C cyclic peptides. U.S. 4,524,135, 1985

9) Palleroni, N.J.: Genus I. Pseudomonas Migula 1894, 237 AL. In Bergey's Manual of Systematic Bacteriology. Volume 1. Eds., N. R. KRIEG \& J. G. HoLt, pp. 140 199, Williams \& Wilkins Co., Baltimore, 1984

10) Stolp, H. \& D. GadKari: Chapter 61. Nonphathogenic members of the genus Pseudomonas. In The Prokaryotes: A Handbook on Habitants, Isolation and Identification of Bacteria. Volume I. Ed., M. P. STARR, pp. 719 741, Spring-Verlag Berlin, Heidenlberg, 1981 